\title{
Research of SMA - 13 Asphalt Mixture Proportioning Design on Northern End of the Capital Airport F Sliding
}

\author{
Shuaituan Tian \& Song Ye \\ China Airport Construction Group Corporation of CACC, Beijing, 100101, China \\ Beijing Super-Creative Technology Co., LTD, Beijing, 100621, China \\ Bin Guo \\ Beijing New Airport Construction Headquarters, China
}

\begin{abstract}
When we go to airport to do something or take plane, we will find that there are a lot of serious rut. the capital F slide northern area reconstruction project is on the construction, so we think we can pass the construction to solve this problem .we research the SMA-13 modified asphalt mixture of capital F slide northern area reconstruction project from any respects, including aggregate, filler, asphalt, fiber and anti-rutting agent, and we hope we can find the best ways to resolve it.
\end{abstract}

KEYWORD: Runway; the raw materials; mixture test Pavement diseases; track

\section{INTRODUCTION}

When the inspectors check to the airport, they report the runway always happens to the rut problem (Xiaoming, Huang, 2004). If the problem will not be solved, it will bring serious impacts on the pavement service, and brings serious security hidden danger; Just now the capital F slide northern area reconstruction project is on the construction, so we think we can pass the construction to solve this problem.

\section{RAW MATERIALS}

\subsection{Asphalt}

Table 1. Cnooc modified asphalt performance test results

\begin{tabular}{|c|c|c|c|}
\hline \multicolumn{2}{|l|}{ Test items } & $\begin{array}{l}\text { Technical } \\
\text { requirements }\end{array}$ & $\begin{array}{l}\text { Test } \\
\text { results }\end{array}$ \\
\hline \multicolumn{2}{|c|}{ Softening point $\left({ }^{\circ} \mathrm{C}\right)$} & $>75$ & 84.3 \\
\hline \multicolumn{2}{|c|}{$\begin{array}{l}\text { Penetration }\left(25^{\circ} \mathrm{C}, 100 \mathrm{~g}, 5 \mathrm{~s}\right) \\
(0.1 \mathrm{~mm})\end{array}$} & $40 \sim 80$ & 53.2 \\
\hline \multicolumn{2}{|c|}{ Ductility $\left(5 \mathrm{~cm} / \mathrm{min}, 10^{\circ} \mathrm{C}\right)(\mathrm{cm})$} & $>40$ & 66.7 \\
\hline \multirow{3}{*}{$\begin{array}{l}\text { Filmy heat- } \\
\text { ing opera- } \\
\text { tional } \\
\text { test } 163^{\circ} \mathrm{C} / 5 \mathrm{~h}\end{array}$} & Mass loss $(\%)$ & $<1$ & 0.024 \\
\hline & $\begin{array}{l}\text { Penetration ratio } \\
(\%)\end{array}$ & $>70$ & 72.5 \\
\hline & $\operatorname{Ductility}\left(10^{\circ} \mathrm{C}\right)(\mathrm{cm})$ & $>30$ & 66.6 \\
\hline \multicolumn{2}{|c|}{ Equivalent softening point $\mathrm{T}_{800}\left({ }^{\circ} \mathrm{C}\right)$} & $>50$ & 55.6 \\
\hline \multicolumn{2}{|c|}{ Equivalent brittle point $\mathrm{T}_{1.2}\left({ }^{\circ} \mathrm{C}\right)$} & $<-13$ & -14.3 \\
\hline \multicolumn{2}{|c|}{ Flash point $(\mathrm{COC})\left({ }^{\circ} \mathrm{C}\right)$} & $>250$ & 282 \\
\hline \multicolumn{2}{|c|}{ Elastic recovery $\left(15^{\circ} \mathrm{C}\right)$} & $>75$ & 96 \\
\hline
\end{tabular}

We use Cnooc asphalt, and we modify it with $6 \%$ SBS modifier, then it will be modified to modified asphalt. We test its performance indicators, the results is shown in table 1 .

From the results, it appears that all the performance indicators meet the technical requirements, we can use this asphalt.

\subsection{Coarse aggregate and fine aggregate}

\subsubsection{Coarse aggregate}

There are basalt coarse aggregates $(10 \sim 15 \mathrm{~mm}$, $5 \sim 10 \mathrm{~mm})$ and limestone $(3 \sim 5 \mathrm{~mm})$ aggregates, we teste the aggregate indexes in accordance with the relevant regulations, the test results are shown in table 2 .

Table 2. The Coarse aggregate technical indicators

\begin{tabular}{|l|l|l|}
\hline Aggregate size & Test results & Test items \\
\hline $10 \sim 15 \mathrm{~mm}$ & 2.793 & $\begin{array}{l}\text { Bulk specific } \\
\text { gravity }\end{array}$ \\
\hline $5 \sim 10 \mathrm{~mm}$ & 2.724 & Apparent spe- \\
cific gravity
\end{tabular}

From the results, it can be get that the bulk specific gravity and the apparent specific gravity all meet the technical requirements, we can use them in the project. 
Table 3. The Coarse aggregate Particle gradation

\begin{tabular}{|c|c|c|c|c|c|c|}
\hline \multirow{3}{*}{$\begin{array}{l}\text { mesh } \\
(\mathrm{mm})\end{array}$} & \multicolumn{6}{|c|}{$\mathrm{P}(\%)$} \\
\hline & \multicolumn{2}{|c|}{$10 \sim 15 \mathrm{~mm}$} & \multicolumn{2}{|c|}{$5 \sim 10 \mathrm{~mm}$} & \multicolumn{2}{|c|}{$3 \sim 5 \mathrm{~mm}$} \\
\hline & $\begin{array}{l}\text { Technical require- } \\
\text { ments }\end{array}$ & $\begin{array}{c}\text { Test re- } \\
\text { sults }\end{array}$ & $\begin{array}{l}\text { Technical require- } \\
\text { ments }\end{array}$ & $\begin{array}{c}\text { Test re- } \\
\text { sults }\end{array}$ & $\begin{array}{l}\text { Technical require- } \\
\text { ments }\end{array}$ & $\begin{array}{c}\text { Test re- } \\
\text { sults }\end{array}$ \\
\hline 16 & - & & - & & - & \\
\hline 13.2 & 100 & & - & & - & \\
\hline 9.5 & 100 & 100 & - & & - & \\
\hline 4.75 & - & 100 & - & & - & \\
\hline 2.36 & $95 \sim 100$ & 85.9 & 100 & 100 & - & \\
\hline 1.18 & $0 \sim 15$ & 49.7 & $95 \sim 100$ & 96.4 & 100 & 100 \\
\hline 0.6 & $0 \sim 5$ & 2 & $0 \sim 10$ & 15.7 & $85 \sim 100$ & 99.8 \\
\hline 0.3 & - & 0 & $0 \sim 5$ & 1.6 & $0 \sim 25$ & 32.4 \\
\hline 0.15 & - & 0 & - & 1.4 & & 6.5 \\
\hline 0.075 & - & 0 & - & 0 & $0 \sim 5$ & 3.2 \\
\hline
\end{tabular}

From table 3 , it can be get that the $2.36 \mathrm{~mm}$ and $1.18 \mathrm{~mm}$ passing rate of $10 \sim 15 \mathrm{~mm}$, the $0.6 \mathrm{~mm}$ passing rate of $5 \sim 10 \mathrm{~mm}$ and the $0.3 \mathrm{~mm}$ passing rate of $3 \sim 5 \mathrm{~mm}$ can not meet the technical requirements. So we suggest that we should screen $10 \sim 15 \mathrm{~mm}$, $5 \sim 10 \mathrm{~mm}$ and $3 \sim 5 \mathrm{~mm}$ until the passing rate meet technical requirements.

\subsubsection{Fine aggregate}

We use $0-3 \mathrm{~mm}$ fine aggregate, we test their performance indicators as shown in table 4.

Table 4. The Basalt FINE aggregate Particle gradation

\begin{tabular}{|c|c|c|}
\hline \multirow{2}{*}{$\begin{array}{l}\text { mesh } \\
(\mathrm{mm})\end{array}$} & \multicolumn{2}{|l|}{$\mathrm{P}(\%)$} \\
\hline & Technical requirements & Test results \\
\hline 4.75 & 100 & 100 \\
\hline 2.36 & $85 \sim 100$ & 83.2 \\
\hline 1.18 & & 52.8 \\
\hline 0.6 & $20 \sim 50$ & 36.7 \\
\hline 0.3 & & 27.3 \\
\hline 0.15 & & 22.9 \\
\hline 0.075 & $0 \sim 15$ & 18.5 \\
\hline
\end{tabular}

From the results, it can be get that the $2.36 \mathrm{~mm}$, $0.6 \mathrm{~mm}$ and $0.15 \mathrm{~mm}$ passing rate of $0 \sim 3 \mathrm{~mm}$ can not meet the technical requirements. So we suggest that We should screen $0 \sim 3 \mathrm{~mm}$ until the passing rate meet technical requirements.

\subsection{Filler}

Table 5. The Mineral filler technical indicators

\begin{tabular}{|c|c|c|c|}
\hline \multicolumn{2}{|l|}{ Test items } & $\begin{array}{l}\text { Technical } \\
\text { requirements }\end{array}$ & Test results \\
\hline \multicolumn{2}{|c|}{ Hydrophilic coefficient } & $\leq 1$ & 0.5 \\
\hline \multirow{3}{*}{$\begin{array}{l}\text { Particle grada- } \\
\text { tion }\end{array}$} & $<0.6 \mathrm{~mm}$ & 100 & 99.4 \\
\hline & $<0.15 \mathrm{~mm}$ & $90 \sim 100$ & 96.3 \\
\hline & $<0.075 \mathrm{~mm}$ & $75 \sim 100$ & 83.7 \\
\hline \multicolumn{2}{|c|}{$\begin{array}{l}\text { Apparent specific gravity } \\
\left(\mathrm{g} / \mathrm{cm}^{3}\right)\end{array}$} & $\geq 2.50$ & 2.776 \\
\hline \multicolumn{2}{|c|}{ Water content $(\%)$} & $\leq 1$ & 0.12 \\
\hline
\end{tabular}

We use the limestone powder filler, we test its performance indicators as shown in table 5 .
From the results, it can be get that all the performance indicators meet the technical requirements, we can use this filler.

\subsection{Fiber}

We use polyacrylonitrile fiber to test, its main technical indicators are shown in table 6.

Table 6. polyacrylonitrie fiber test results

\begin{tabular}{|l|l|l|}
\hline Test items & $\begin{array}{l}\text { Technical } \\
\text { requirements }\end{array}$ & Test results \\
\hline Diameter $(\mu \mathrm{m})$ & $10 \sim 25$ & 12.4 \\
\hline Length $(\mathrm{mm})$ & $6 \pm 1.5$ & 6.3 \\
\hline $\begin{array}{l}\text { Tensile } \\
\text { strength }(\mathrm{MPa})\end{array}$ & $\geq 500$ & 525 \\
\hline $\begin{array}{l}\text { Elongation at } \\
\text { break }(\%)\end{array}$ & $\geq 15$ & 17.8 \\
\hline
\end{tabular}

From table 6, we can see all the indicators of polyacrylonitrile fiber meet the specification requirements, and it can be used in the design and engineering.

\subsection{Anti-rutting agent}

We use haichuan Anti-rutting agent, through results, Adding $0.5 \%$ anti-rutting agent of the asphalt mixture we can achieve the best test results. We test its performance indicators, we put the results is shown in table 7.

Table 7. Anti rutting agent basic indexes test results

\begin{tabular}{|l|l|l|}
\hline Test items & $\begin{array}{l}\text { Technical re- } \\
\text { quirements }\end{array}$ & Test results \\
\hline Density $\left(\mathrm{g} / \mathrm{cm}^{3}\right)$ & $0.9 \sim 1.1$ & 0.94 \\
\hline $\begin{array}{l}\text { Melt flow rate }\left(190^{\circ} \mathrm{C},\right. \\
2.16 \mathrm{~kg})(\mathrm{g} / 10 \mathrm{~min})\end{array}$ & $\geq 3$ & 8 \\
\hline Water content $(\%)$ & $\leq 2$ & 0.5 \\
\hline Softening point $\left({ }^{\circ} \mathrm{C}\right)$ & $110 \sim 150^{\circ} \mathrm{C}$ & 141 \\
\hline
\end{tabular}

From table 7, it can be get that all the performance indicators meet the technical requirements, we can use haichuan Anti-rutting agent. 
3 MIX DESIGN OF SMA-13 ASPHALT MIXTURE

\subsection{The determination of aggregate gradation ratio}

The aggregate gradation ratio of SMA-13 asphalt mixture is formed with $t$ five different raw materials. We choose three mix designs. All the mix designs and raw materials are shown in table 8 , table 9 and figure 1 .

Table 8. SMA-13 ratio of mineral aggregate gradation (\%)

\begin{tabular}{|l|l|l|l|l|l|}
\hline Specifications & $\begin{array}{l}10 \sim 15 \\
\mathrm{~mm}\end{array}$ & $\begin{array}{l}5 \sim 10 \\
\mathrm{~mm}\end{array}$ & $\begin{array}{l}3 \sim 5 \\
\mathrm{~mm}\end{array}$ & $\begin{array}{l}0 \sim 3 \\
\mathrm{~mm}\end{array}$ & filler \\
\hline $\begin{array}{l}\text { Coarse grada- } \\
\text { tion }\end{array}$ & 15 & 24 & 10 & 26 & 5 \\
\hline $\begin{array}{l}\text { Middle grada- } \\
\text { tion }\end{array}$ & 15 & 24 & 10 & 26 & 5 \\
\hline Fine gradation & 15 & 24 & 10 & 26 & 5 \\
\hline
\end{tabular}

Table 9. SMA-13 mineral synthesis aggregate gradation

\begin{tabular}{|l|l|l|l|l|l|}
\hline $\begin{array}{l}\text { Mesh } \\
\text { size }(\mathrm{mm})\end{array}$ & coarse & middle & fine & upper & lower \\
\hline 26 & 100.0 & 100.0 & 100.0 & 100 & 100 \\
\hline 19 & 100.0 & 100.0 & 100.0 & 100 & 100 \\
\hline 16 & 100.0 & 100.0 & 100.0 & 100 & 100 \\
\hline 13.2 & 92.8 & 93.0 & 93.1 & 100 & 90 \\
\hline 9.5 & 73.4 & 74.0 & 74.5 & 65 & 45 \\
\hline 4.75 & 28.1 & 29.9 & 31.7 & 34 & 22 \\
\hline 2.36 & 18.8 & 19.9 & 21.0 & 27 & 18 \\
\hline 1.18 & 15.4 & 16.0 & 16.6 & 22 & 14 \\
\hline 0.6 & 13.7 & 14.1 & 14.5 & 19 & 12 \\
\hline 0.3 & 12.9 & 13.2 & 13.5 & 16 & 10 \\
\hline 0.15 & 12.4 & 12.6 & 12.9 & 14 & 9 \\
\hline 0.075 & 10.6 & 10.8 & 11.0 & 12 & 8 \\
\hline
\end{tabular}

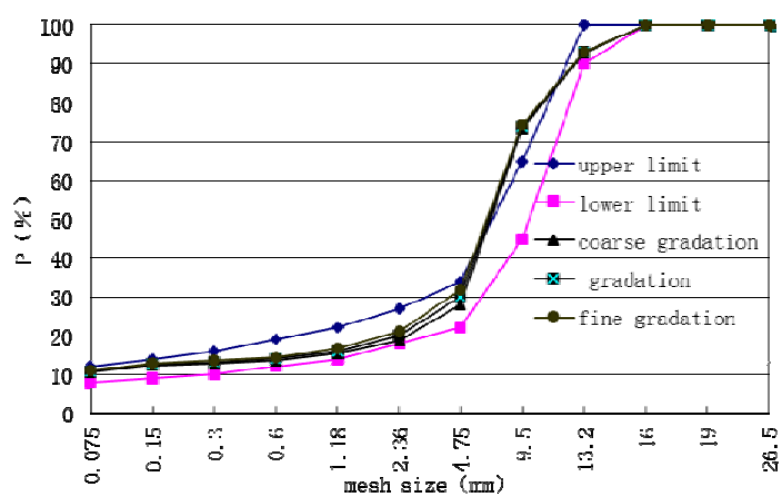

Figure 1. SMA-13 grading curve

Table 10. The Marshall test results of different asphalt aggregate ratio

\begin{tabular}{|c|c|c|c|c|c|}
\hline items & $\begin{array}{c}\text { loose } \\
\text { unit } \\
\text { weight } \\
\left(\mathrm{g} / \mathrm{cm}^{3}\right)\end{array}$ & $\begin{array}{c}\text { passing } \\
\text { rate of } \\
4.75 \\
\mathrm{~mm}(\%)\end{array}$ & $\begin{array}{c}\text { bulk specific } \\
\text { gravity of } \\
\text { above } \\
4.75 \mathrm{~mm} \\
\left(\mathrm{~g} / \mathrm{cm}^{3}\right)\end{array}$ & $\mathrm{P}_{\mathrm{CA}}$ & VCA $_{\text {DRC }}$ \\
\hline coarse & 1.606 & 28.1 & 2.797 & 0.678 & 42.59 \\
\hline middle & 1.615 & 29.9 & 2.795 & 0.661 & 42.21 \\
\hline fine & 1.622 & 31.7 & 2.780 & 0.644 & 41.65 \\
\hline
\end{tabular}

Content of coarse aggregate PCA and Clearance rate VCADRC of more than $4.75 \mathrm{~mm}$ in three mixtures are tested in table 10.

Based on the experience of previous similar airport engineering, we use ratio of $6.0 \%$ as a first try oil-stone ratio in Marshall Design method, and then mold specimens in accordance with the specification requirements, measure the physical indexes of the specimens. Specific data are shown in table 11.

Table 11. Performance of the first grading

\begin{tabular}{|c|c|c|c|}
\hline Test items & $\begin{array}{l}\text { Coarse } \\
\text { gradation }\end{array}$ & $\begin{array}{l}\text { Middle } \\
\text { gradation }\end{array}$ & Fine gradation \\
\hline $\begin{array}{l}\text { Bulk specific } \\
\text { gravity }\left(\mathrm{g} / \mathrm{cm}^{3}\right)\end{array}$ & 2.454 & 2.460 & 2.468 \\
\hline $\begin{array}{l}\text { Theoretical } \\
\text { density }\left(\mathrm{g} / \mathrm{cm}^{3}\right)\end{array}$ & 2.566 & 2.565 & 2.565 \\
\hline VV (\%) & 4.38 & 4.10 & 3.78 \\
\hline VMA (\%) & 16.51 & 16.33 & 16.08 \\
\hline VFA (\%) & 73.5 & 74.9 & 76.5 \\
\hline $\mathrm{VCA}_{\operatorname{mix}}(\%)$ & 40.50 & 41.79 & 42.79 \\
\hline $\operatorname{VCA}_{\text {DRC }}(\%)$ & 42.59 & 42.21 & 41.65 \\
\hline $\mathrm{MS}(\mathrm{KN})$ & 8.09 & 8.28 & 9.13 \\
\hline $\mathrm{FL}(0.1 \mathrm{~mm})$ & 27.4 & 26.4 & 28.4 \\
\hline
\end{tabular}

According to the relevant specifications, the coarse grading is the best grading.

\subsection{The determination of the optimum proportion}

Table 12. The Marshall test results of different asphalt aggregate ratio

\begin{tabular}{|l|l|l|l|l|}
\hline \multirow{2}{*}{ Test items } & \multicolumn{3}{|l|}{ Oil-stone ratio $(\%)$} & \multirow{2}{*}{$\begin{array}{l}\text { Specification } \\
\text { requirements }\end{array}$} \\
\cline { 2 - 4 } & 5.7 & 6.0 & 6.3 & \\
\hline $\begin{array}{l}\text { Bulk specific } \\
\text { gravity }\left(\mathrm{g} / \mathrm{cm}^{3}\right)\end{array}$ & 2.438 & 2.445 & 2.461 & - \\
\hline $\begin{array}{l}\text { Theoretical } \\
\text { density }\left(\mathrm{g} / \mathrm{cm}^{3}\right)\end{array}$ & 2.577 & 2.566 & 2.556 & - \\
\hline VV $(\%)$ & 5.4 & 4.7 & 3.7 & $3 \sim 4$ \\
\hline VMA $(\%)$ & 16.8 & 16.8 & 16.5 & $\geq 16.5$ \\
\hline VFA $(\%)$ & 67.9 & 71.9 & 77.5 & - \\
\hline VCA $m$ mix $(\%)$ & 40.30 & 40.30 & 40.09 & $\leq \mathrm{VCA}_{\text {DRC }}$ \\
\hline VCA $_{\text {DRC }}(\%)$ & 42.19 & 42.19 & 42.19 & - \\
\hline MS $(\mathrm{KN})$ & 8.33 & 7.81 & 7.54 & $\geq 6$ \\
\hline FL $(0.1 \mathrm{~mm})$ & 29.5 & 28.3 & 27.6 & - \\
\hline
\end{tabular}

We select 3asphalt aggregate ratio of Marshall test and calculate their physical indicators in order to determine the optimum proportion, the test results are shown in table 12.

According to the requirements of the relevant specification, calculated the optimum proportion of $6.1 \%$.

\subsection{The optimum proportion of validation}

In the optimum asphalt aggregate ratio of $6.1 \%$, we make Marshall Specimen and the dynamic stability 
of specimen, then test their Physical and mechanical performance. The results is shown in table 13.

Table 13. The Road performance verification test results

\begin{tabular}{|l|l|}
\hline Test items & Test results \\
\hline$\triangle \mathrm{M}(\%)$ & 0.07 \\
\hline$\triangle \mathrm{S}(\%)$ & 3.5 \\
\hline $\mathrm{DS}($ time/mm) & 10299 \\
\hline $\mathrm{MSo}(\%)$ & 86.6 \\
\hline $\mathrm{TSR}(\%)$ & 84.8 \\
\hline $\mathrm{Cw}(\mathrm{mL} / \mathrm{min})$ & 36.7 \\
\hline $\mathrm{TD}(\mathrm{mm})$ & 0.82 \\
\hline
\end{tabular}

From the results, it can be get that all the test results can meet the requirements of related technologies.

\section{CONCLUSION}

In combination with the capital $\mathrm{F}$ slide northern area reconstruction project, in order to solve the serious rut of SMA - 13 asphalt mixture, we achieve these important ways.

First: Starting from the raw material, we should choose the qualified raw materials.

Second: we should choose good aggregate gradation.

Third: In order to obviously improve the dynamic stability of mixture, it is reasonable to adding antirutting agent.

\section{REFERENCES}

The civil aviation administration of China. JTG F40-2004. Specification for asphalt concrete pavement construction of civil airports [S].

The ministry of communications highway engineering science institute. JTG E42-2005. Test methods of aggregate for Highway Engineering [S].

The ministry of communications highway engineering science institute. JTJ E20-2011.Standard test methods of bitumen and bituminous mixtures for highway engineering [S].

Xiaoming, Huang. Asphalt and asphalt mixture [M]. The ministry of communications highway engineering science institute. JTG F40-2004. Technical specification for construction of highway asphalt pavement [S]. 